\title{
経静脈的糖負荷試験による胃癌患者の耐糖能に関する検討
}

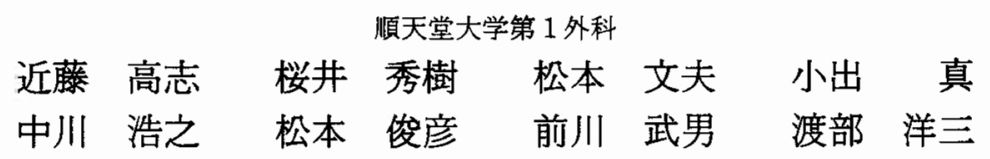

\section{A CLINICAL STUDY ON GLUCOSE TOLERANCE IN PATIENTS WITH GASTRIC CANCER BY INTRAVENOUS GLUCOSE INJECTION}

\author{
Takashi KONDOH, Hideki SAKURAI, Fumio MATUMOTO, \\ Makoto KOIDE, Hiroyuki NAKAGAWA, Toshihiko MATUMOTO, \\ Takeo MAEKAWA and Yohzoh WATANABE \\ 1st Department of Surgery, Juntendoh University School of Medicine
}

\begin{abstract}
胃癌症例34例に経静脈的糖負荷試験を施行し，その成績を stage 別，癌腫の大きさ別に比較検討し た. stage 別では stage I, II, III, IV の 4 群に, また癌腫の大きさ別では早期癌を A 群, 進行癌を腫 诲長径が $5 \mathrm{~cm}$ 以内を $\mathrm{B}$ 群, 5 $10 \mathrm{~cm}$ を $\mathrm{C}$ 群, $10 \mathrm{~cm}$ 以上を $\mathrm{D}$ 群の 4 群に分けた。血糖値は stage III, IV およびC 群がそれぞれ stage I, A 群にくらべ有意に高值を示した. IRI は C 群，D群が A 群にく

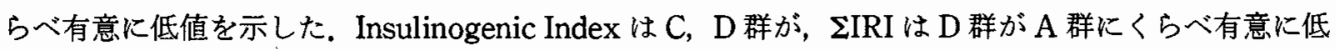
值を示した. 以上, stage III 以上, 腫瘍径 $5 \mathrm{~cm}$ 以上の進行癌で耐糖能低下が認められた。この耐糖能 低下の原因として癌患者の栄養低下による影響が大きいと考えられた。
\end{abstract}

索引用語：胃癌症例の耐糖能, 経静脈的糖負荷試験, インスリン

\section{1. 緒 言}

消化器倁患を有する患者は栄養状態が低下している ことが多い，中でる担癌患者では，腫瘍による食物通 過障害, 蛋白異化が加わっているため栄養低下が著し い.このような症例では術前高かロリー輸液を要する 例も多く，栄養管理は治療の成否をも左右する重要な 問題である1). 栄養管理においては個々の症例の耐糖 能の把握が不可欠であるが, 癌患者では前述した低栄 養のほかに飢餓, ストレス, 出血, また腫湯の存在自 体などが，それぞれの程度により耐糖能低下因子とし て働くことが多い，このため糖㽷病素因のなかった症 例でも耐糖能が低下していることもあり栄養管理の上 でとくに注意を要する。

今回著者らは胃癌の糖代謝に及洔す影響を検討する 目的で胃癌症例に経静脈的糖負荷試験 (iv-GTT) を行 ない，いくつかの検討を試みた。

\section{II. 対 象}

対象は，当科で手術を行った胃癌症例34例で，早期

$<1987$ 年 4 月15日受理 > 別刷請求先：近藤 高志

干113 文京区本郷 2-1-1 順天堂大学医学部第 1 外科
癌 8 例, 進行癌26例である. 糖尿病例, 肝転移例, 肝 障害例，その他耐糖能に影響を及ばす合併症を有する 症例を除外した。

これら34例を胃癌取り扱い規約2)の病理組織学的 stage 分類にもとづき stage I：12例, stage II：4 例, stage III：8例, stage IV：10例に分けた. しかし, この stage 分類では, 癌腫の大きさがかならずしも stage 進行度に反映されないため, 腫瘍の大ささによ る分類も行った。すなわち, $\mathrm{A}$ 群 (早期癌：8 例), $\mathrm{B}$ 群 (腫瘍径 $5 \mathrm{~cm}$ 以内の進行癌：9例), $\mathrm{C}$ 群 (腫瘍径 $5 \sim 10 \mathrm{~cm}$ の進行度： 8 例), $\mathrm{D}$ 群 (畽場径 $10 \mathrm{~cm}$ 以上の 進行癌：9例）に分け前述の stage 分類も併せて検討 した.

\section{III. 方 法}

術前の早朝空腹時に $50 \%$ ブドウ糖 $20 \mathrm{ml}$ を 1 分間で 时静脈から静注し, 採血は対側肘静脈より, 負荷前, 負荷後 2 分, 5 分, 10 分, 30 分, 60 分, 90 分, に行っ た．血糖は全血を用いHoffmann 法 (オートアナライ ザー法)で,インスリンは 2 抗体法で測定した。

測定数値はすべて平均値士標準誤差で表わし，統計 処理は student's t-testにて行った. 
IV. 結 果

1. stage 分類による検討

各群の年跉には差はなかった。

体重減少量（健康時体重一入院時体重）は stage IV で最も多く, stage I に比べ有意 $(\mathrm{p}<0.05)$ の減少を 示した。肥満度, T.P, albumin も stage IV で低值を 示したが，有意差はなかった（表 1 ）。

各群の負荷前の血糖值は, stage III が最も高く stage I に比べ有意（p<0.05）に高値を示した。負荷 後の血糖値は, stage IV が終始最も高い值となり， 5 分, 10 分, 30 分で stage I K比べ有意 $(\mathrm{p}<0.05)$ に高 く，60分でも高い傾向を示したまをた stage III は，10 分值で stage I に比べ有意 $(\mathrm{p}<0.05)$ に高値となった。

表 1 胃癌進行度

\begin{tabular}{|c|c|c|c|c|c|}
\hline & 年 竞 & 体曹娍少(kg) & 肥灌度 (\%) & $T-P(g / d \mathscr{C})$ & Albumin(g/de) \\
\hline stage I & $55.3 \pm 5$ & $2.0 \pm 0.8$ & $106 \pm 4$ & $6.6 \pm 0.1$ & $4.0 \pm 0.1$ \\
\hline stage II & $52.5 \pm 8$ & $3.4 \pm 1.7$ & $108 \pm 10$ & $6.7 \pm 0.3$ & $3.5 \pm 0.3$ \\
\hline stage III & $53.6 \pm 4$ & $3.2 \pm 1.2$ & $103 \pm 3$ & $6.6 \pm 0.2$ & $4.0 \pm 0.1$ \\
\hline stage $N$ & $54.2 \pm 3$ & $5.6 \pm 1.5$ & $95 \pm 4$ & $6.5 \pm 0.2$ & $3.7 \pm 0.2$ \\
\hline
\end{tabular}

図 1 胃癌 stage と IV-GTT 時血糖曲線

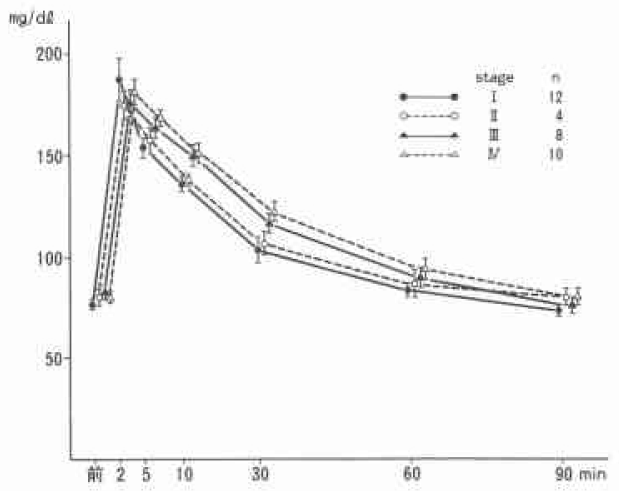

因 2 胃癌 stage と IV-GTT 時 IRI 曲線

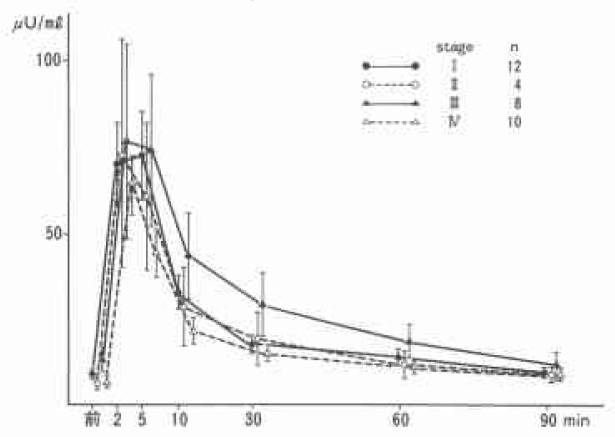

以上 stage 別の血糖曲線の検討では， stage IV で明 らかな耐糖能低下が認められた（図 1 ）。

同時に測定した IRI 值は，負荷前は各群に差はな かった。負荷後は, stage IVで低值を示したが，他の 3 群とほとんど差はなかった（図 2).

\section{2. 胃癌腫瘍径による検討}

各群の年齢に差はなかった。

体重減少量は，D群で最も著しく，A 群との間に有 意差 $(\mathrm{p}<0.05)$ を認めた。肥満度, T.P も D 群が最も 低く, 肥満度では $\mathrm{A}$ 群と $\mathrm{D}$ 群, $\mathrm{B}$ 群と $\mathrm{D}$ 群の間に, T-Pでは B 群と C 群, B 群と D 群との間に有意差 （p<0.05）を認めた. Albumin は C 群が最も低く, B 群との間に有意差 $(\mathrm{p}<0.05)$ を認めた（表 2$)$.

負荷前の血糖値は $\mathrm{C}$ 群が最も高く, A 群, B 群との 間に有意差 $(\mathrm{p}<0.05)$ を認めた。負荷後, 各時点の血 糖值は, B 群, C 群, D 群が A 群に比べ高値を示し, $\mathrm{B}$ 群は30分值で有意 $(\mathrm{p}<0.05)$ の高値を，また $\mathrm{C}$ 群は 10 分, 30 分, 90 分值で, $\mathrm{D}$ 群は30分值で A 群に比べ高 値となる傾向がみられた（図 3）。

インスリンは, 負荷前值は各群で差はなかった。負 荷後は D 群が著しい低分泌で，A 群と比べ， 2 分值 $(\mathrm{p}<0.05) ， 5$ 分， 10 分値 $(\mathrm{p}<0.01)$ で有意の低下を 示した. C 群も初期低分泌であり，A 群に比べ 5 分值 で有意（ $p<0.05 ）$ の低下を示した（図 4$)$.

Insulinogenic index $(\Delta \mathrm{IRI} / \Delta \mathrm{BS})$ は腫瘍径の増大と

表 2 胃癌腫瘍径

\begin{tabular}{|c|c|c|c|c|c|c|}
\hline & 年 㱓 & 体重減少 (kg) & 眠㳻囯 & $T-P(\mathrm{~g} / \mathrm{d} \ell)$ & Albumin(g/de) \\
\hline A 群 & 早期癌 & $53 \pm 4$ & $1.7 \pm 1.0$ & $107 \pm 4$ & $6.7 \pm 0.2$ & $4.0 \pm 0.2$ \\
\hline B 群 & $\sim 5 \mathrm{~cm}$ & $53 \pm 5$ & $3.7 \pm 1.0$ & $110 \pm 6$ & $6.9 \pm 0.2$ & $4.0 \pm 0.1$ \\
\hline C 群 & $5 \sim 10 \mathrm{~cm}$ & $58 \pm 4$ & $3.2 \pm 1.2$ & $104 \pm 4$ & $6.5 \pm 0.1$ & $3.6 \pm 0.1$ \\
\hline D群 & $10 \mathrm{~cm} \sim$ & $58 \pm 3$ & $6.4 \pm 1.7$ & $92 \pm 3]$ & $6.3 \pm 0.2$ & $3.8 \pm 0.1$ \\
\hline
\end{tabular}

図 3 胃癌腫瘍径と IV-GTT 時血糖曲線

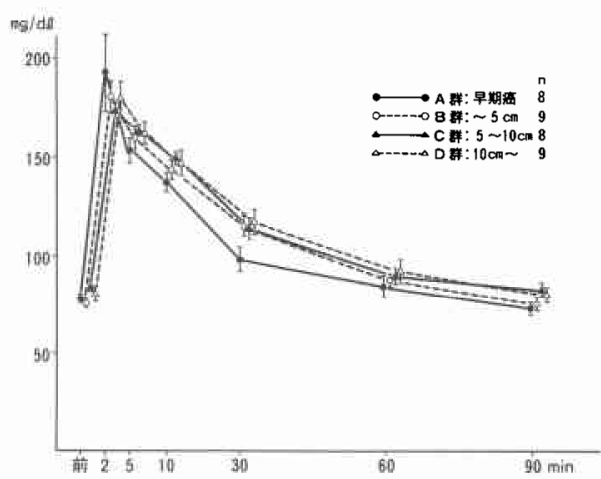


図 4 胃癌腫瘍径と IV-GTT 時 IRI 曲線

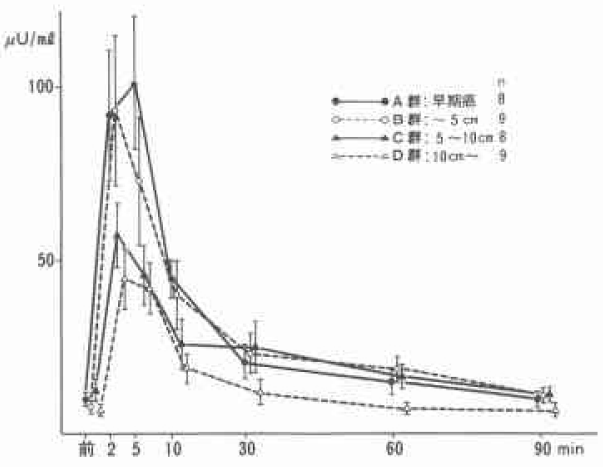

図 5 胃癌腫瘍径と Insulinogenic index $\Delta \mathrm{IRI} / \triangle \mathrm{BS}(0 \sim 5$ 分 $)$

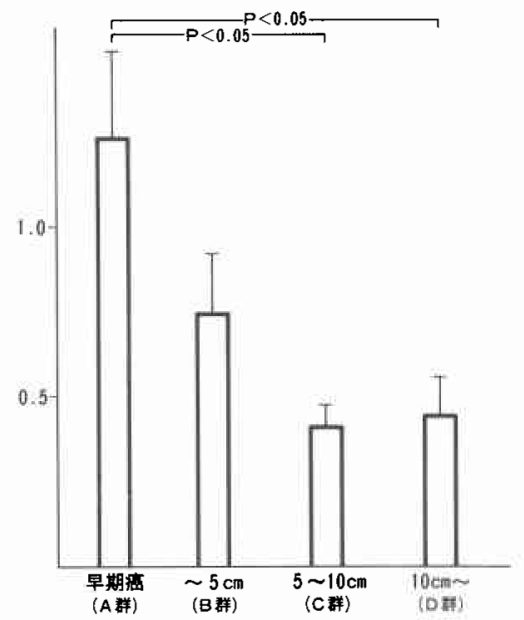

伴に低下し，C 群，D 群は，A 群に比べ有意 $(\mathrm{p}<0.05)$ に低下した（図５）。

総インスリン分泌量 ( $\Sigma$ IRI) も同様に D 群は A に比 ベ有意 $(\mathrm{p}<0.01)$ に低下した（図6）.

腫瘍径別の検討では B 群, C 群, D 群で耐糖能低下, C 群，D群でインスリン分泌低下が認められた。

\section{V. 考 察}

癌患者の耐糖能障害については, 古くは1885年に Freund $^{3)}$ による癌患者で高血糖の頻度が高いといら 報告がある。との後 Glicksman² は628例の癌患者と 322例の非癌患者に経口糖負荷試験（o-GTT）を行い, 癌患者で $36.7 \%$, 非癌患者では $8.3 \%$ 症例に糖尿病型 血糖曲線がみられたと報告している。高たLundholm ${ }^{5)}$ は 19 人の癌患者と 12 人の非癌患者に経静脈糖負荷試験 を行い，癌患者に括ける耐糖能，インスリン分泌能低 下を報告している。しかしこれらの検索対象にはあら ゆる種類の癌が含まれて拉り，その進行度も不明であ
図 6 胃癌腫瘍径と総インスリン分泌量（IIRI）

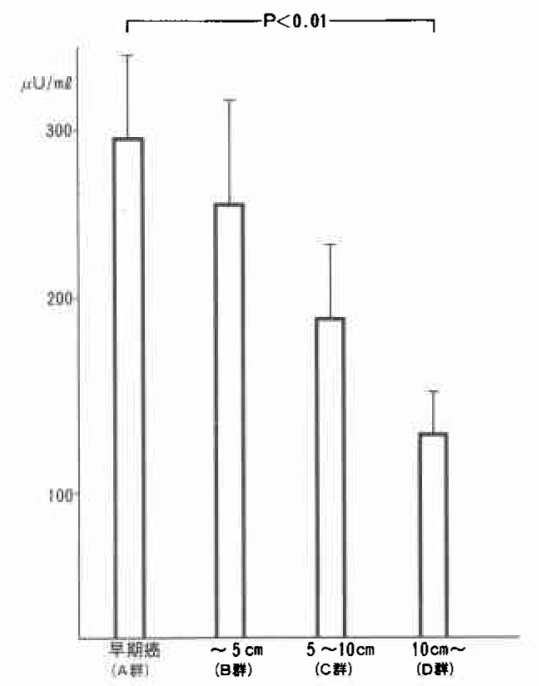

る、一般に耐糖能は栄養状態，出血，ストレス，感染 などに影響を受けるが，担癌臓器により，また癌の進 行度により上記諸因子の異なる病態が出現し，耐糖能 を検討する上で混乱を来すおそれすある。この意味で, 担癌体の糖代謝異常を論じる時, 対象を同一臓器の癌 とし，交た進行度別に検討する必要があると思われる。 著者らは，検索対象を本邦での頻度が高い胃癌とした が，担癌体の糖代謝に関する研究は主に欧米での報告 が多いためか，胃癌についての検討はほとんどない。

胃癌患者は，摂食障害から栄養低下を来しやすく，高 カロリー輸液を要する症例もあり, 胃癌症例の耐糖能 を知ることは, 術前術後の栄養管理上の観点からも重 要である，また同じ胃癌であってもその進行度により 早期のものから末期のものまであり，耐糖能にも差が あると考えられるが, 癌の進行度と耐糖能に関寸る報 告も汪とんどない，著者らは，胃癌症例に経静脈糖負 荷試験（iv-GTT）を行い，胃癌進行度（stage 分類） や癌腫の大きさによる耐糖能の変化を検討した。その 結果, 血糖値は負荷後各時点で, stage の進行, 癌腫の 増大とともに耐糖能が低下する傾向がみられた。一方， インスリン分泌は, stage 分類に和いては注とんど差 を認めなかったが，腫湢径による比較では，腫瘍径の 増大とともにインスリン分泌の低下がみられ，またInsulinogenic index, 総インスリン分泌量も，腫瘍径の 増大とともに有意に低下した。

進行癌患者の耐糖能低下の原因として，第 1 にイン スリン分泌低下が考えられる．岸ら ${ }^{6}$ は胃癌症例に $20 \mathrm{~g}$ iv-GTTを行い stage 別の比較検討で, stage III, IV で著しいインスリン初期分泌低下を認めている. Lun- 
dholm, 和田 ${ }^{7)}$ もれぞれ iv-GTT, o-GTTの成績 で，癌患者でインスリン分泌の低下を報告しており， 進行癌に拈いて, 糖負荷に対するインスリン分泌能は 低下するとの報告が多い, しかし, Carter ら 少のない乳癌患者に $100 \mathrm{~g}$ 0-GTT を行い, 耐糖能低下 を認めたが, インスリン分必は，正常対照に比べむし ろやや増大していたと報告している，著者らの成績で あ stage 分類による検討では, stage の進行とともに 耐糖能は悪化するがインスリン分泌は低下せず，その 成績はかならずしも一致していない，その理由を著者 らは検索対象の栄養度による差ではないかと考学てい る、栄養と酎糖能，インスリン分泌について, Smith ら9はインドの高度低栄養患者にo-GTTを行い, 耐糖 能，インスリン分泌ともに著しく低下していると報告 しており，またWeinkove'(0)は，iv-GTT，トルブタマ イド試験による検討で, 低栄養食で飼育した ratでイ ンスリン初期分泌の低下を報告している，以上のごと く低栄屓はインスリン分泌を低下させるが，担癌体の インスリン分泌について, 諸家の報告を栄養度の良悪 に着目してみると, 進行癌症例であってもCarter ら の報告のように対象が乳癌で経口摂取も可能で, 栄養 が保たれている場合には,インスリン分泌は低下せず, 岸6), Lundholm 5 5) 栄養障害の強い症例を対象とし た検討ではインスリン分泌は低下しているようであ る.著者らの腫瘍径別の検討でも，腫痬径の増大とと むにインスリン分泌は低下し，また各種栄養指標も著 しい低下を示し, 癌に伴う栄養障害とインスリン分泌 低下は密に関連していると推察された。

担癌体の耐糖能低下の第 2 の原因として, 癌患者に おけるインスリン感受性低下があげられる. Lundholm ら5)は, 10名の癌患者のインスリン注射後の血糖 值の変化から, 癌患者ではインスリン注射に対する血 糖の反射が弱まって扣り，健常者に比ベインスリン抵 抗性が高まっていると報告している。われわれの結果 でも, 負荷前の血糖値と IRI 值を対比してみると, IRI 値には各群で差はないが, 血糖値は胃癌 stageの進行 とともに, また腫瘍径の増大と共に有意に高倌を示し, 間接的ながら進行癌患者におけるインスリン感受性低 下を示唆するものと考えられる。

以上のごとくインスリン分泌低下は栄養度と密に関 連し, またインスリン抵抗性増大も加わり, 癌患者の 耐糖能障害の原因となりらる可能性について述べた。

担癌体の糖代謝異常の解明にはこの他蛋白, 脂質代
謝も含めた検討が必要であり，な打多くの問題が残さ れている、今後, 担癌体の詳細な代謝経路, ホルモン 動態の解明により悪液質に陥るのを防ぐ有効な治療が 生まれれば，癌に対する直接の治療とともにその予後 の改善に貢献するものと期待される.

$$
\text { おわりに }
$$

胃癌症例の摘出標本の検索により stage 分類, 腫瘍 径による分類を行いiv-GTTによる耐糖能を比較検 討し, stage III 以上, 腫瘍径 $5 \mathrm{~cm}$ 以上の症例で耐糖能 低下，インスリン分泌低下が認められた. stage 分類は 術前に把握できないが, 腫瘍径は胃 $\mathrm{X}$ 線, 内視鏡検査 で把握可能で, 術前に知りらる1つの目安としては, 腫瘍径が $5 \mathrm{~cm}$ 以上の症例で耐糖能低下例が多いこと に留意すべきであろう。また来院時すでに栄養障害に 陷っている症例では, 術前から高カロリー輸液が必要 であるが, 低栄責はまた耐糖能悪化の原因となるため, 高カロリー輸液施行時の血糖管理には十分な注意を要 すると考光られる。

\section{文献}

1）佐藤 真：胃癌患者の栄養評価に関する臨床的研 究一術前栄養状態の計量化による術後合併症予測 指数の作成一. 日外会誌 $83: 66-77,1982$

2）胃癌研究会編：胃癌取り扱い規約. 改訂第11版, 東 京, 金原出版, 1985

3) Freund E: Zur diagnose des carcinoms. Wien Med B1 8:268-269, 1885

4) Glicksman AS, Rauson RW: Diabetes and altered carbohydrate metabolism in patient with cancer. Cancer 9:1127-1134, 1956

5) Lundholm K, Holm G, Schersten $T$ : Insulin resistanse in patient with cancer. Cancer Res $38: 4665-4670,1978$

6) 岸清志, 河野菊弘, 澄川 学: 胃癌患者の耐糖 能. 外科診療 $58: 1012-1015,1984$

7）和田武雄, 鬼原 彰, 野尻義男 : 担癌生体と内分泌 環境異常とくに血中膵ホルモン動態の検討。癌と 化療 5:128-134, 1978

8) Carter AC, Lefkon BW, Farlin M: Metabolic parameters in women with metastatic breast cancer. J Clin Endoclinol Metab 40:260-264, 1975

9) Smith SR, Edger PJ, Pozesky $T$ et al: Insulin secretion and glucose tolerance in adults with protein-carlorie malnutrition. Metabolism 24 : $1073-1084,1975$

10) Weinkove C, Weinkove EA, Pimstone BL: Glucose tolerance and insulin release in malnourished rats. Clin Sci Mol Med $50: 153-163$, 1976 